\title{
mDAG: a web-based tool for analyzing microarray data with multiple treatments
}

\author{
Vinhthuy T Phan ${ }^{1 *}$, Nam S Vo², Thomas R Sutter ${ }^{3}$ \\ From 10 ${ }^{\text {th }}$ Annual UT-ORNL-KBRIN Bioinformatics Summit 2011 \\ Memphis, TN, USA. 1-3 April 2011
}

\section{Background}

In microarray experiments involving multiple treatments, pairwise comparisons between all pairs of treatments are desirable but expensive. To cope with this, we previously introduced a method that performed all pairwise comparisons in a post hoc manner. This method employs directed graphs to represent gene response to pairs of treatments. It has been applied and found useful in identifying and differentiating genes sharing similar functional pathways $[1,2]$.

\section{Results}

mDAG is a web-based software based on this method. mDAG allows users to upload microarray data in GCT format through a web interface. From this data, the application performs calculations to assign graphical patterns to genes and outputs images and textual data for further analyses. These graphical patterns carry specific meanings in terms of how genes respond to pairs of treatments. The application is implemented using Python and web2py.

mDAG is available at http://cetus.cs.memphis. edu:8080/mDAG.

\section{Conclusion}

For experiments involved multiple treatments and replicates, mDAG allows researchers to analyze and visualize in graphical representations relationships of gene interactions to all pairs of treatments. The software can be used online or off-line.

\footnotetext{
* Correspondence: vphan@memphis.edu

'Department of Computer Science, University of Memphis, Memphis, TN, 38152, USA

Full list of author information is available at the end of the article
}

\section{Acknowledgements}

This software is supported by the Center for Alternatives to Animal Testing at the John Hopkins school of Public Heath, Project CAAT-2011-18.

\section{Author details}

${ }^{1}$ Department of Computer Science, University of Memphis, Memphis, TN, 38152, USA. ${ }^{2}$ Bioinformatics Program, University of Memphis, Memphis, TN, 38152, USA. ${ }^{3}$ Department of Biological Sciences, University of Memphis, Memphis, TN, 38152, USA.

Published: 5 August 2011

\section{References}

1. Phan V, George EO, Tran QT, Goodwin S, Boddreddigari S, Sutter TR: Analyzing microarray data with transitive directed acyclic graphs. Journal of Bioinformatics and Computational Biology 2009, 7(1):135-156.

2. Tran QT, Lijing X, Phan V, Goodwin S, Rahman M, Jin V, Sutter CH, Roebuck B, Kensler T, George EO, Sutter TR: Chemical genomics of cancer chemopreventive dithiolethiones. Carcinogenesis 2009, 30(3):480-486.

\section{doi:10.1186/1471-2105-12-S7-A7}

Cite this article as: Phan et al:: mDAG: a web-based tool for analyzing microarray data with multiple treatments. BMC Bioinformatics 201112 (Suppl 7):A7.
Submit your next manuscript to BioMed Central and take full advantage of:

- Convenient online submission

- Thorough peer review

- No space constraints or color figure charges

- Immediate publication on acceptance

- Inclusion in PubMed, CAS, Scopus and Google Scholar

- Research which is freely available for redistribution
C Biomed Central

\section{Biomed Central}

